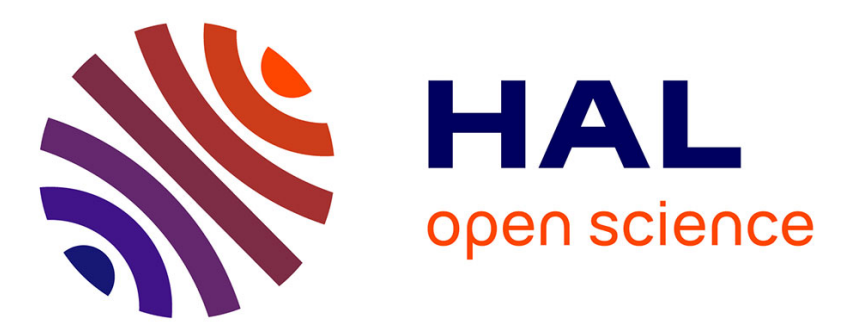

\title{
Comparison of real-time PCR and droplet digital PCR for the detection of Xylella fastidiosa in plants
}

\author{
Enora Dupas, Bruno Legendre, Valérie Olivier, Françoise Poliakoff, Charles
} Manceau, Amandine Cunty

\section{- To cite this version:}

Enora Dupas, Bruno Legendre, Valérie Olivier, Françoise Poliakoff, Charles Manceau, et al.. Comparison of real-time PCR and droplet digital PCR for the detection of Xylella fastidiosa in plants. Journal of Microbiological Methods, 2019, 162, pp.86-95. 10.1016/j.mimet.2019.05.010 . hal-02628944

\section{HAL Id: hal-02628944 \\ https://hal.inrae.fr/hal-02628944}

Submitted on 25 Oct 2021

HAL is a multi-disciplinary open access archive for the deposit and dissemination of scientific research documents, whether they are published or not. The documents may come from teaching and research institutions in France or abroad, or from public or private research centers.
L'archive ouverte pluridisciplinaire HAL, est destinée au dépôt et à la diffusion de documents scientifiques de niveau recherche, publiés ou non, émanant des établissements d'enseignement et de recherche français ou étrangers, des laboratoires publics ou privés.

\section{(ㄷ)(1) $\$$}

Distributed under a Creative Commons Attribution - NonCommercial| 4.0 International 


\section{Comparison of real-time PCR and droplet digital PCR for the 2 detection of Xylella fastidiosa in plants}

3 Enora Dupas $^{1,2^{*}}$, Bruno Legendre ${ }^{1}$, Valérie Olivier ${ }^{1}$, Françoise Poliakoff $^{1}$, Charles Manceau ${ }^{1}$, 4 Amandine Cunty ${ }^{1}$

$5{ }^{1}$ French Agency for Food, Environmental and Occupational Health \& Safety, Plant Health

6 Laboratory, Angers, France

72 IRHS, INRA, Agrocampus-Ouest, Université d'Angers, SFR 4207 QuaSaV, 49071,

8 Beaucouzé, France

$9 *$ Corresponding author:

10 Enora Dupas

11 enora.dupas@anses.fr

12 ORCID: 0000-0002-4233-3108

13 Declarations of interest: The authors have no competing interests to declare. 


\section{Abstract}

Xylella fastidiosa $(\mathrm{Xf})$ is a quarantine plant pathogen bacterium originating from the Americas and that has emerged in Europe in 2013. $X f$ can be detected directly on plant macerate using molecular methods such as real-time PCR, which is a sensitive technique. However, some plants may contain components that can act as PCR reaction inhibitors, which can lead to false negative results or an underestimation of the bacterial concentration present in the analyzed plant sample. Droplet digital PCR (ddPCR) is an innovative tool based on the partitioning of the PCR reagents and the DNA sample into thousands of droplets, allowing the quantification of the absolute number of target DNA molecules present in a reaction mixture, or an increase of the detection sensitivity. In this study, a real-time PCR protocol, already used for $X f$ detection in the framework of official surveys in the European Union, was transferred and optimized for $X f$ detection using ddPCR. This new assay was evaluated and compared to the initial real-time PCR on five plant matrices artificially inoculated and on naturally infected plants. In our conditions, this new ddPCR enabled the detection of $X f$ on all artificially inoculated plant macerates with a similar limit of detection, or a slight benefit for Quercus ilex. Moreover, ddPCR improved diagnostic sensitivity as it enabled detection of $X f$ in samples of Polygala myrtifolia or $Q$. ilex that were categorized as negative or close to the limit of detection using the real-time PCR. Here, we report for the first time a ddPCR assay for the detection of the bacterium $X f$.

Keywords: Xylella fastidiosa, ddPCR, molecular diagnostics, quarantine plant pathogenic bacteria.

\section{Introduction}

Xylella fastidiosa $(X f)$ is a plant pathogenic bacterium known worldwide. Located in the xylem vessels of plants, its natural way of transmission is sap-feeding insect vectors (Almeida and Nunney, 2015). To date, five different subspecies (subsp.) have been described: subsp. fastidiosa, subsp. morus, subsp. multiplex, subsp. pauca, and subsp. sandyi (Nunney et al., 2014; Schaad et al., 2004; Schuenzel et al., 2005). In Europe, $X f$ was first detected in Italy, in the Apulia area in 2013, where the subsp. pauca was identified on olive trees (Saponari et al., 2013). Then, in France in 2015 (Corsica and in French Riviera region), the subsp. multiplex was reported firstly on Polygala myrtifolia and then on a large range of ornamental or wild plants (Denancé et al., 2017). More recently in 2016, the subsp. fastidiosa, multiplex and 
pauca were identified in the Balearic Islands (Spain), on olive trees, grapevines and sweet cherry trees; and in 2017, the presence of the subsp. multiplex was also identified in Spain near Alicante, on almond trees (Landa, 2017). Currently, 563 plant species distributed in 82 botanical families are reported to be hosts of $X f$, and this list includes plants of major socioeconomic interest such as olive trees, citrus or grapevine (EFSA, 2018). Since 2017, $X f$ has been classified in Annex I/A2 of Council Directive 2000/29/EC revised in 2017, and in the A2 list of the EPPO as a quarantine pathogen present on the EU territory and requiring mandatory control (C/2017/4883, 2017; EPPO, 2018a).

Since its detection in Italia, $X f$ has proven to be a threat to European plant production. In the Apulia Region, the infected area increased from 8000 to 715000 ha between 2013 and 2018 (Saponari et al., 2019). This led, in 2015, to the area becoming a containment zone instead of an eradication zone. In 2018, this area covered 36\% of the region and threatened about 21 million olive trees. In mainland Spain, since the first identification of $X f$, the infected area has extended to 87800 ha and 47 almonds orchards have been found positive for $X f$ (Bucci, 2018). Spain being the world's second largest producer of almonds with 255503 tons produced in 2017, $X f$ could become a threat to the world almond production (FAOSTAT, 2017). In France, in Corsica, 350 foci were identified in 2017. As the infection could not be stopped, this has led to the declaration of the entire island as area under containment (Implementation Decision 2017/2352, 2017). Risk models predicted that in the South-East the lower part of the Durance basin and the Rhône valley were moderate to high risk areas for $X f$ infection (Martinetti and Soubeyrand, 2019). All these regions, known for their production of citrus, vines, olive trees or fruit orchards, are of great economic value for France. As no therapeutic solution has been found to control the disease, early detection and eradication of outbreaks are essential to prevent the spread of $X f$ in Europe.

As isolation and cultivation of $X f$ is fastidious, detection and identification tests are applied directly on plant extracts (Denancé et al., 2017). Nowadays, different molecular tools targeting specific DNA regions are available to detect the bacterium at the species level or to specifically detect one of the subspecies. Conventional PCRs such as Minsavage et al. (2014) have been developed, but they are less sensitive than Real-Time PCR (Baldi and La Porta, 2017). Among the real-time PCR techniques developed, the method designed by Harper et al. (2010) was identified as one of the most suitable methods for $X f$ detection. It allow to detect all the $X f$ subspecies, its limit of detection determined on different plant species is low, it is 
sensitive, and no cross-reactions with other bacterial species have been reported (Francis et al., 2006; Harper et al., 2010; Li et al., 2013; Modesti et al., 2017; Ouyang et al., 2013).

Even though real-time PCR is very sensitive in most cases, low bacterial contamination levels of plants and the presence of PCR inhibitors can lead to false negative results, and the underestimation of positive samples for some plant species (Modesti et al., 2017; Schrader et al., 2012). These PCR inhibitors include polyphenols, polysaccharides, pectin and xylan (Harper et al., 2010; Schrader et al., 2012; Wei et al., 2008). Studies have revealed that the improvement of DNA extraction methods, or the addition of bovine serum albumin (BSA) during the PCR assay, may reduce the impact of PCR inhibitors (Harper et al., 2010; Schrader et al., 2012). For some plants, such as Nerium oleander, Prunus dulcis and Vitis vinifera, a tenfold dilution prevented PCR inhibition and led to successful detection of $X f$ (Francis et al., 2006; Minsavage et al., 1994; Modesti et al., 2017). However, DNA dilution cannot be applied to every sample, due to low $X f$ concentrations in some infected plants. It can therefore be rather difficult to find a universal method, because of the wide range of $X f$ host plants. Moreover, even though real-time PCR produces quantitative data when using a calibration curve, the results are often only interpreted qualitatively for $X f$ detection (Cruaud et al., 2018; Modesti et al., 2017).

Digital PCR was set up in 1999 by Vogelstein and Kinzler and named later by Morley in 2014. By compartmentalizing the PCR reaction into thousands of droplets, ddPCR offers the promises of absolute quantification without the need for calibration (Hindson et al., 2011; Huggett et al., 2013; Morley, 2014; Voegel and Nelson, 2018; Vogelstein and Kinzler, 1999). At first, ddPCR was designed to identify rare mutations in a small number of cells (Vogelstein and Kinzler, 1999). Already used for medical purposes (Bharuthram et al., 2014; Cao et al., 2015; Hindson et al., 2011; Nixon et al., 2014; Ramírez et al., 2019), this method was transferred as a detection and quantification tool to other fields, such as environmental sciences (Doi et al., 2015; Hoshino and Inagaki, 2012), food safety control (Bian et al., 2015; Wang et al., 2018), GMO detection (Košir et al., 2017; Morisset et al., 2013) or the agronomic field (Dreo et al., 2014; Maheshwari et al., 2017; Rački et al., 2014; Voegel and Nelson, 2018; Zhao et al., 2016). The transfer of real-time PCR assays to ddPCR assays has already provided successful results for the detection and the quantification of plant pathogenic bacteria (Dreo et al., 2014; Lu et al., 2019; Maheshwari et al., 2017; Zhao et al., 2016). For example, ddPCR was more efficient than real-time PCR to detect low concentrations of 
Ralstonia solanacearum in potatoes (Dreo et al., 2014). It also increased the detection

110 threshold of other pathogens such as Xanthomonas citri subsp. citri in citrus, Pepper mild 111 mottle virus in plants, soil and water, or of GMOs in maize seed powder (Morisset et al., 112 2013; Rački et al., 2014; Zhao et al., 2016). ddPCR was reported to be up to 1,000 fold more 113 sensitive than conventional PCR developed to detect adenovirus in live attenuated vaccines 114 (Dong et al., 2018). It allows the detection and quantification of pathogen abundance, such as 115 Agrobacterium vitis in grapevines, for which previous methods lacked sensitivity (Voegel and 116 Nelson, 2018). An additional advantage of ddPCR is its tolerance to PCR inhibitors present in 117 plants, soil, water or food (Cao et al., 2015; Maheshwari et al., 2017; Morisset et al., 2013; 118 Rački et al., 2014; Zhao et al., 2016). ddPCR presents many advantages that could make it an 119 alternative for $X f$ detection.

120 The aim of this study was to transfer the real-time PCR developed by Harper et al. (2010) into a ddPCR assay, in order to improve the detection of $X f$ at low concentrations in plant matrices rich in PCR inhibitors. ddPCR was compared to real-time PCR using five artificially inoculated plant matrices and naturally infected plants sampled in France. The plant species used as matrices were selected for their level of PCR inhibitors reported by the Plant Health Laboratory (PHL) of the French Agency for Food, Environmental and Occupational Health \& Safety (ANSES) following the analysis of thousands of different plant samples collected since 2015 in the context of the national $X f$ survey in France (personal communication, Bruno Legendre). Polygala myrtifolia was selected as a matrix containing a low concentration of inhibitors, Lavandula angustifolia, Olea europaea, Quercus ilex and Rosmarinus officinalis were selected as matrices containing high concentrations of inhibitors. Experimental assays were set up following the standard PM7/98 and the digital MIQE guidelines. The following

132 performance criteria were evaluated: analytical sensitivity, repeatability, and diagnostic 133 specificity (EPPO, 2014; Huggett et al., 2013).

\section{Materials and methods}

\section{$2.1 \quad$ Bacterial strains}

136 Bacterial strains $X f$ subsp. multiplex CFBP 8416, isolated in France (Corsica) in 2015 from 137 symptomatic P. myrtifolia (Denancé et al., 2017) and Xf subsp. fastidiosa CFBP 7970, 138 isolated in the United States (Florida) from Vitis vinifera were cultivated on modified PWG 139 media at $28^{\circ} \mathrm{C}$ for two weeks (EPPO, 2018b). Bacterial suspensions of pure culture of $X f$ were 
prepared in sterile demineralized water and suspensions titer was estimated by

141 immunofluorescence (IF) (EPPO, 2018b, 2009). The antiserum, used to count $X f$, was

142 especially produced in collaboration with the UR1268 BIA - Team Allergy of the French

143 National Institute for Agricultural Research (INRA) of Angers-Nantes. It resulted from the

144 inoculation of rabbits with nine strains of $X f$ chosen to be as diverse as possible in terms of

145 subspecies, geographical location, and host plant species. The initial concentration of the

146 CFBP 8416 bacterial suspension was estimated by IF at $1.84 \times 10^{9}$ bacteria/mL (b/mL). This

147 suspension was used to spike all the artificially inoculated samples in this study. The bacterial

148 suspension of the strain CFBP 7970 was calibrated at $1 \times 10^{7} \mathrm{~b} / \mathrm{mL}$ and used as a positive

149 control for the PCR reactions.

\subsection{Plant materials}

151 Healthy plant materials used for spiking assays were collected in 2018. L. angustifolia, O.

152 europaea, $Q$. ilex, $R$. officinalis were sourced from Maine-et-Loire, a French department 153 known to be $X f$ free. $P$. myrtifolia was produced in a nursery in Brittany ( $X f$ free) and had a 154 European phytosanitary passport certifying its healthy status. Moreover, no symptoms were 155 recorded on these five plants. In this study, the healthy status of the five matrices was first 156 checked using the real-time PCR assay Harper et al. (2010).

157 Naturally infected samples of Calicotome sp. (one sample), L. angustifolia (four samples), $P$. 158 myrtifolia (13 samples), and Q. ilex (4 samples) were collected in the context of the national 159 survey, between 2016 and 2018 in Corsica and in the PACA region of France. These 22 160 samples were already found to have a positive status or to be at the limit of detection by the 161 PHL, using the real-time PCR developed by Harper et al. (2010).

\section{$162 \quad 2.3 \quad$ Plant spiking}

163 The artificially inoculated plant samples were prepared by mixing $1 \mathrm{~g}$ of healthy plant petiole 164 in $4.5 \mathrm{~mL}$ of sterile demineralized water and spiked with $0.5 \mathrm{~mL}$ of a known concentration of 165 bacterial suspension. Each matrix was spiked in order to reach a range dilution of $1 \times 10^{5} \mathrm{~b} / \mathrm{mL}$; $1665 \times 10^{4} \mathrm{~b} / \mathrm{mL} ; 1 \times 10^{4} \mathrm{~b} / \mathrm{mL} ; 5 \times 10^{3} \mathrm{~b} / \mathrm{mL} ; 1 \times 10^{3} \mathrm{~b} / \mathrm{mL} ; 5 \times 10^{2} \mathrm{~b} / \mathrm{mL} ;$ and $1 \times 10^{2} \mathrm{~b} / \mathrm{mL}$. The 167 negative template control (NTC) was obtained by mixing $1 \mathrm{~g}$ of healthy plant petiole with 5 $168 \mathrm{~mL}$ of sterile demineralized water. 
170 The bacterial strain suspension used as a positive control for all the PCRs was inactivated by

171 thermal lysis. A volume of $1 \mathrm{~mL}$ of bacterial suspension was heated at $100^{\circ} \mathrm{C}$ for 5 min and

172 then frozen at $-20^{\circ} \mathrm{C}$ for at least $15 \mathrm{~min}$.

173 The plants to be spiked and the naturally infected samples were homogeneously crushed in an 174 extraction bag (Bioreba AG, Basel, Switzerland) with a pneumatic press prior DNA 175 extraction. Extraction, washing, and elution of the DNA were automated using KingFisher ${ }^{\mathrm{TM}}$ $176 \mathrm{~mL}$ (Thermo Scientific). DNA extracts were kept at $4{ }^{\circ} \mathrm{C}$ for a week, or stored at $-20^{\circ} \mathrm{C}$ for a 177 longer period.

\subsection{Real-time PCR Harper et al., 2010}

179 The real-time PCR assays were performed on the thermal cycler CFX96 real-time System 180 C1000 Touch (Bio-Rad), using 96-well plates (Hard-Shell ${ }^{\circledR}$ 96-Well PCR Plates, \#hsp9601, 181 Bio-Rad). The following thermal cycling program used was: $50^{\circ} \mathrm{C}$ for $2 \mathrm{~min}, 94^{\circ} \mathrm{C}$ for 10 $182 \mathrm{~min}$, then 40 cycles of two step of $94^{\circ} \mathrm{C}$ for $10 \mathrm{~s}$ and $62^{\circ} \mathrm{C}$ for $40 \mathrm{~s}$. The reaction mix was 183 prepared in a final volume of $20 \mu \mathrm{L}$ containing: 1x TaqMan Fast Universal Master Mix

184 (Applied Biosystems), $300 \mathrm{nM}$ of each $X f$ forward and reverse primers (XF-F and $X F-\mathrm{R}$, 185 respectively), $100 \mathrm{nM}$ of 6'FAM/BHQ-1 labeled probe (XF-P), $300 \mu \mathrm{g} / \mu \mathrm{L}$ of BSA, and $2 \mu \mathrm{L}$ 186 of DNA sample. $2 \mu \mathrm{L}$ of lysed suspension of the strain CFBP 7970 at $1 \times 10^{7} \mathrm{~b} / \mathrm{mL}$ was added 187 as positive control for each PCR run. Two negative controls were used: a) sterile 188 demineralized water, b) the extracted DNA from each healthy plant previously artificially 189 inoculated with sterile demineralized water. For the artificially contaminated plant material, 190 each sample was amplified in triplicate and on three independent PCR runs to obtain nine $\mathrm{Ct}$ 191 values per sample. For the naturally infected plant material, each sample was amplified in 192 duplicate on the same PCR run.

193 The data acquisitions and data analyses were performed using Bio-Rad CFX Manager, v 3.0.

194 The determination of $\mathrm{Ct}$ values is done using the regression mode of the software, which 195 applies a multivariable, nonlinear regression model to individual well traces and then uses this 196 model to compute an optimal Ct value (Bio-Rad, 2008). This allowed all Ct results to be 197 compared within and between PCR plates. A Ct higher than 38 was considered to be a 198 negative result, according to the cut-off indicated by (Harper et al., 2010). For all the 199 following analyses, the limit of detection was fixed at $100 \%$, meaning the lowest 
concentration at which all replicates gave a positive signal. The efficiency of the real-time

201 PCR amplification was estimated from the slope of each standard curve using the equation: $\mathrm{E}$ $202=-1+10^{(-1 / \text { slope })}$.

203

204

205

206

207

208

209

210

211

212

213

214

215

216

217

218

219

220

221

222

223

224

225

226

227

228

229

230

\subsection{Optimization and evaluation of the ddPCR assay}

Two thermal gradients were tested to determine the optimal hybridization temperature ranging from 54.6 to $64.6^{\circ} \mathrm{C}$, and from 57 to $62^{\circ} \mathrm{C}$. Thermal gradients were applied on samples of $P$. myrtifolia, spiked with suspensions of $X f$ ranging from $1 \times 10^{5} \mathrm{~b} / \mathrm{mL}$ to $1 \times 10^{3} \mathrm{~b} / \mathrm{mL}$. BSA was tested at the concentration determined by Harper et al. (2010) (300 $\mu \mathrm{g} / \mu \mathrm{L})$ on a sample of $P$. myrtifolia spiked with $X f$ at a concentration of $1 \times 10^{5} \mathrm{~b} / \mathrm{mL}$. In order to optimize the assay for the five matrices spiked at $1 \times 10^{5} \mathrm{~b} / \mathrm{mL}$, four different DNA volumes added to the reaction mix were tested: $2 \mu \mathrm{L} ; 4 \mu \mathrm{L} ; 6 \mu \mathrm{L}$ and $8 \mu \mathrm{L}$. Using the optimized protocol, tenth dilutions of $L$. angustifolia and $R$. officinalis spiked with $1 \times 10^{3} \mathrm{~b} / \mathrm{mL}$ were tested. All the experiments conducted to optimize the ddPCR assay were amplified in triplicate. For each ddPCR assay the positive and negative controls used were the same as for the qPCR described above.

\subsection{Optimized ddPCR assay}

The optimized ddPCR reaction mix conditions retained were a final reaction volume of $20 \mu \mathrm{L}$ containing: $1 \mathrm{x}$ ddPCR ${ }^{\mathrm{TM}}$ Supermix for Probes (No dUTP) (Bio-Rad), $900 \mathrm{nM} \mathrm{Xf}$ forward and reverse primers ( $X F-\mathrm{F}$ and $X F-\mathrm{R}), 250 \mathrm{nM}$ 6'FAM/BHQ-1 labeled probe $(X F-\mathrm{P})$, and $8 \mu \mathrm{L}$ of DNA sample. Droplets were generated with the QX200 ${ }^{\mathrm{TM}}$ Droplet Digital ${ }^{\mathrm{TM}}$ System (BioRad) in a cartridge containing $20 \mu \mathrm{L}$ of the reaction mix and $70 \mu \mathrm{L}$ of Droplet Generation Oil for Probes (ddPCR TM 96-Well Plates \#12001925, Bio-Rad). The entire emulsion volume was transferred from the cartridge to a 96-well PCR plate (Bio-Rad) and the PCRs were performed on the thermal cycler CFX96 real-time System C1000 Touch (Bio-Rad). Optimal thermocycling conditions retained were: DNA polymerase activation of $95^{\circ} \mathrm{C}$ for $10 \mathrm{~min}$, then 40 cycles of two-steps of $94^{\circ} \mathrm{C}$ for $30 \mathrm{~s}$ for denaturation and $59^{\circ} \mathrm{C}$ for $60 \mathrm{~s}$ for hybridization and elongation, followed by a final step at $98^{\circ} \mathrm{C}$ for $10 \mathrm{~min}$ for droplet stabilization. According to Bio-Rad recommendations, a temperature ramp of $2^{\circ} \mathrm{C} / \mathrm{s}$ was fixed on all PCR steps and the lead was heated at $105^{\circ} \mathrm{C}$. After amplification, the PCR plate was directly transferred to the droplet reader QX200 ${ }^{\mathrm{TM}}$ Droplet Digital ${ }^{\mathrm{TM}}$ System (Bio-Rad). QuantaSoft 1.7.4.0917 software was used for data acquisition and data analysis. The entire concentration 
231 range of spiked matrices was first amplified in triplicate on the same run. Then, for each 232 matrix, samples with concentrations equal to and below the limit of detection identified by 233 real-time PCR were amplified in triplicate on two other independent runs, in order to 234 ultimately obtain nine results for these samples. Finally, the amplifications of the naturally 235 infected samples were performed in one replicate in one run.

\section{$236 \quad 2.8 \quad$ ddPCR analysis}

237 Data were analyzed directly with QuantaSoft ${ }^{\mathrm{TM}}$ Analysis Pro software. For each plate and 238 each matrix, a threshold was manually set up just above the amplitude value of the cloud 239 corresponding to the negative droplets, also considered as the background, and according to 240 the results of the corresponding NTC (Lievens et al., 2016). This threshold enabled the 241 differentiation of droplets by categorizing them as positive (high level of fluorescence) or 242 negative (low and constant level of fluorescence). The PCR reactions with fewer than 10,000 243 droplets generated were excluded from the analysis, and a result was considered positive if at 244 least two positive droplets were detected. The software provided the results in target copies by 245 reaction using the following formula:

$$
C=-\ln \left(1-\frac{P}{P+N}\right) * \frac{1}{\mathrm{~V}}
$$

247 Where $\mathrm{C}$ corresponded to the concentration in target DNA copies/well (cp/well), $\mathrm{P}$ the 248 positive droplet number, $\mathrm{N}$ the negative droplet number, and $\mathrm{V}$ the mean volume in $\mu \mathrm{L}$ of one 249 droplet. According to Bio-Rad, V is equal to $0.85 \times 10^{-3} \mu \mathrm{L}$. Primers and probe targeted a part 250 of the rimM gene, which is present in a single copy in the $X f$ genome. Therefore, the result 251 can be directly converted into $\mathrm{cp} / \mu \mathrm{L}$ in the initial samples, by multiplying it with the total 252 volume of reaction mix $(20 \mu \mathrm{L})$, and then dividing it by the volume of DNA sample added to 253 the reaction mix $(8 \mu \mathrm{L})$ at the beginning of the assay.

254 A bias, meaning the under or over-estimation of the quantification estimated by ddPCR, in 255 comparison with the expected concentration, was calculated with the following formula: 


\section{Results}

258

259

260

261

262

263

264

265

\subsection{Optimization of the ddPCR assay}

The ddPCR appeared to be efficient for $X f$ detection at all tested temperatures. The first thermal gradient tested allowed us to identify $58.5^{\circ} \mathrm{C}$ as the most suitable hybridization temperature, for which positive droplets showed the highest fluorescence amplitude and were well distinguished from the negative droplets. The second thermal gradient confirmed this preliminary result and made it possible to fix the optimum hybridization temperature for ddPCR at $59^{\circ} \mathrm{C}$. At this temperature, positive droplets presented the highest fluorescence amplitude, the less "rain" (i.e. droplets ranging between the positive and negative ones), and better separation from negative droplets (data not shown).

Addition of BSA to the reaction mix did not increase the number of droplets amplified, the number of target DNA detected, nor the amplitude of the fluorescence signal. However, as it increased the standard deviation between replicates, no BSA was added for the optimized ddPCR protocol retained in this study (data not shown).

Like for O. europaea shown in Figure 1, $X f$ detection was successful for all the five matrices, regardless of the volume of DNA extract added to the PCR mix (Supplemental Data 1). The increase of the DNA volume in the mix has improved the sensitivity of the DNA copy detection. Nevertheless, the presence of inhibitors could be highlighted in $Q$. ilex and $R$. officinalis as the amount of target DNA detected was not proportional with the volume of DNA tested. As the aim of the ddPCR assay in this study was also to improve the limit of detection of $X f$ in low-level contaminated samples, the final volume of DNA chosen was $8 \mu \mathrm{L}$. This corresponded to the highest volume of DNA that could be added to ddPCR reaction mix in this study. 


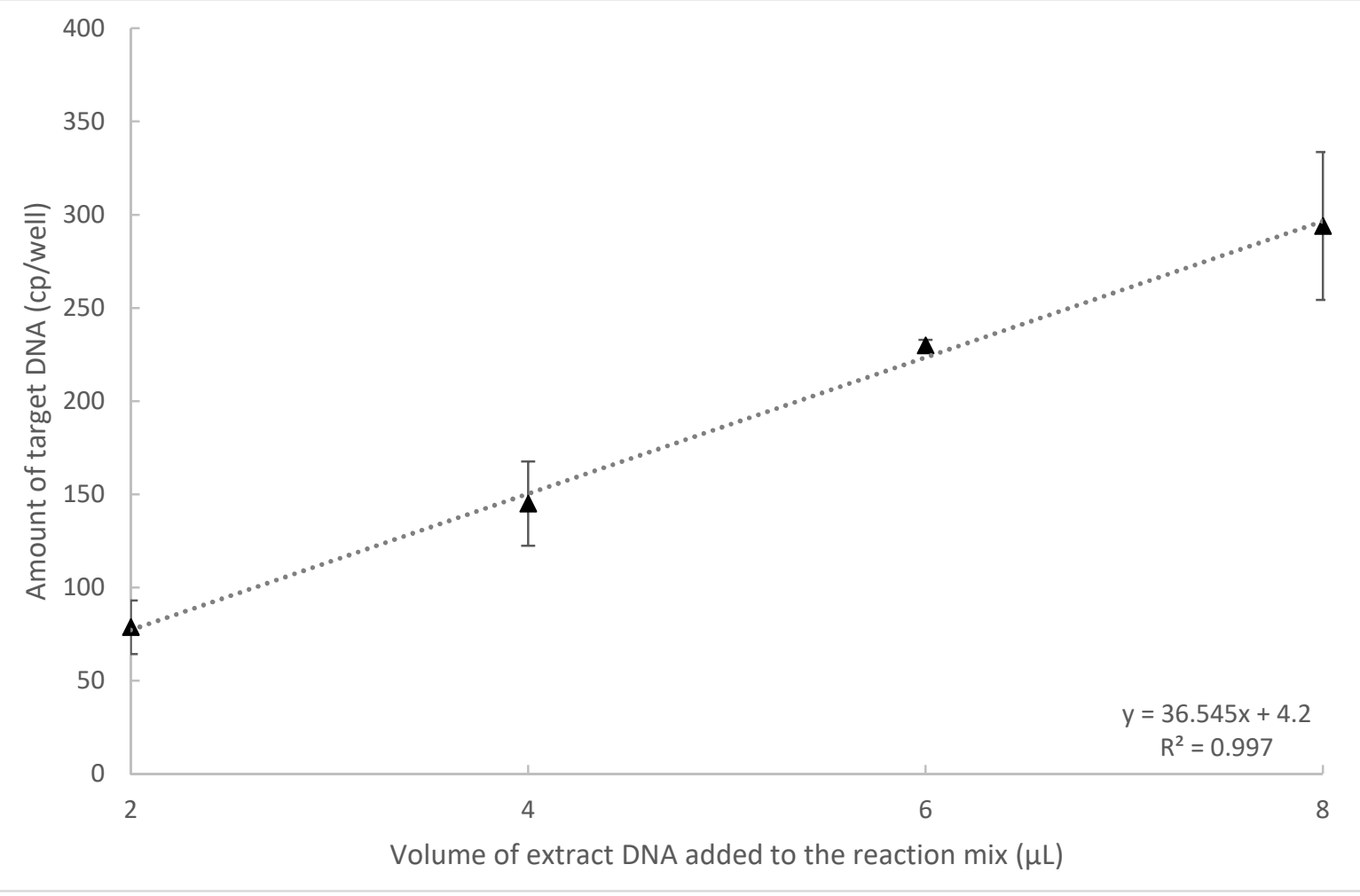

281 Figure 1: Influence of the DNA extract volume added to the ddPCR reaction mix on the 282 amount of DNA target detected for $O$. europaea. 
284 A tenth dilution of the DNA of $L$. angustifolia and $R$. officinalis spiked with $1 \times 10^{3} \mathrm{~b} / \mathrm{mL}$, 285 corresponding to the first concentration under the limit of detection obtained with ddPCR, 286 was tested. For L. angustifolia, none of the six replicates provided positive droplets. In only 287 one of the six replicates tested for $R$. officinalis, two positive droplets were detected. Dilution 288 of the DNA extract of L. angustifolia and R. officinalis did not improve the limit of detection 289 or was not reproducible enough in this study.

\subsection{Xf detection by ddPCR in spiked plant samples}

291 The healthy status of the five plants was validated before spiking, by applying real-time PCR 292 Harper et al. (2010). Indeed, no Ct value was obtained for all the five plant matrices (Table 293 1). As expected, in these assays, no cross-reaction was found, as no positive droplets were 294 found for any of the NTCs, for the plant matrices. Regression curves were constructed to 295 reveal the relationship between the expected concentration versus the measured concentration. 296 All the ddPCR matrix standard curves showed high linearity as the correlation coefficient $\left(\mathrm{R}^{2}\right)$ 297 was higher than 0.96 (supplemental data 2). This indicated the successful outcomes and good performances of all the assays (Table 2). 
Table 1: Mean Ct values obtained with real-time PCR for the bacterial suspension and the five spiked plant matrices.

\begin{tabular}{|c|c|c|c|c|c|c|c|c|c|c|c|c|}
\hline \multirow{2}{*}{$\begin{array}{l}\begin{array}{l}\text { Dilution range } \\
\text { (b/mL) }\end{array} \\
1 \times 10^{5}\end{array}$} & \multicolumn{2}{|c|}{ Bacterial suspension } & \multicolumn{2}{|c|}{ L. angustifolia } & \multicolumn{2}{|c|}{ O. europaea } & \multicolumn{2}{|c|}{ P. myrtifolia } & \multicolumn{2}{|l|}{ Q. ilex } & \multicolumn{2}{|c|}{ R. officinalis } \\
\hline & $32.18 \pm 0.38^{\mathrm{a}}$ & $(9)^{b}$ & $30.76 \pm 0.18$ & (9) & $36.02 \pm 0.43$ & (9) & $30.38 \pm 0.17$ & (9) & $31.85 \pm 0.10$ & (9) & $32.24 \pm 0.17$ & (9) \\
\hline $5 \times 10^{4}$ & $33.14 \pm 0.45$ & $(9)$ & $31.24 \pm 0.11$ & (9) & $36.59 \pm 0.99$ & (9) & $31.41 \pm 0.18$ & (9) & $32.00 \pm 0.15$ & (9) & $32.53 \pm 0.14$ & (9) \\
\hline $1 \times 10^{4}$ & $35.46 \pm 0.64$ & (9) & $33.68 \pm 0.20$ & (9) & $37.32 \pm 0.05$ & (3) & $33.85 \pm 0.34$ & (9) & $34.90 \pm 0.50$ & (9) & $34.83 \pm 0.66$ & (9) \\
\hline $5 \times 10^{3}$ & $35.55 \pm 0.21$ & (9) & $34.93 \pm 0.20$ & (9) & $37.86 \pm 0.49$ & (2) & $34.59 \pm 0.28$ & (9) & $35.31 \pm 0.55$ & (9) & $36.09 \pm 1.05$ & (9) \\
\hline $1 \times 10^{3}$ & $37.42 \pm 0.37$ & (6) & $37.45 \pm 0.58$ & (9) & $37.78 \pm 0.53$ & (2) & $38.00 \pm 0.56$ & (9) & $37.62 \pm 0.86$ & (7) & $38.05 \pm 0.50$ & (6) \\
\hline $5 \times 10^{2}$ & $38.81 \pm 0.12$ & $(5)$ & $37.44 \pm 0.00$ & (1) & $36.61 \pm 0.00$ & (1) & $37.62 \pm 0.18$ & (5) & $37.76 \pm 0.29$ & (4) & $38.25 \pm 0.13$ & (4) \\
\hline $1 \times 10^{2}$ & $38.00 \pm 0.19$ & (6) & $38.46 \pm 1.01$ & (2) & nd & (0) & $38.29 \pm 0.13$ & (4) & $36.75 \pm 0.19$ & (6) & nd & (0) \\
\hline 0 & $\mathrm{nd}^{\mathrm{c}}$ & $(0)$ & nd & (0) & nd & (0) & nd & (0) & nd & (0) & nd & $(0)$ \\
\hline
\end{tabular}

300 a.: Average $\mathrm{Ct} \pm$ Standard Deviation (SD)

$301 \quad$ b: Number of positive replicates on nine replicates analyzed

302 c: Not detected 


\begin{tabular}{rll}
\hline & Curve equation & $\mathrm{R}^{2}$ \\
\hline ddPCR & & \\
Bacterial suspension & $\mathrm{y}=0.41 \mathrm{x}+1136.66$ & 0.99 \\
L. angustifolia & $\mathrm{y}=0.85 \mathrm{x}+2007.35$ & 0.96 \\
O. europaea & $\mathrm{y}=0.02 \mathrm{x}+1016.11$ & 1.00 \\
$P$. myrtifolia & $\mathrm{y}=0.90 \mathrm{x}-781.02$ & 1.00 \\
Q. ilex & $\mathrm{y}=0.36 \mathrm{x}+1187.91$ & 0.99 \\
R. officinalis & $\mathrm{y}=0.37 \mathrm{x}+1363.74$ & 0.98
\end{tabular}

304

\begin{tabular}{rlll}
\hline & Curve equation & $\mathrm{R}^{2}$ & Efficiency \\
\hline Real-time PCR & & & \\
Bacterial suspension & $\mathrm{y}=-2.75 \mathrm{x}+46.06$ & 0.97 & $131.01 \%$ \\
L. angustifolia & $\mathrm{y}=-3.43 \mathrm{x}+47.61$ & 0.99 & $95.68 \%$ \\
O. europaea & $\mathrm{y}=-1.89 \mathrm{x}+45.49$ & 0.98 & $238.14 \%$ \\
P. myrtifolia & $\mathrm{y}=-3.71 \mathrm{x}+48.80$ & 0.99 & $86.01 \%$ \\
Q. ilex & $\mathrm{y}=-3.02 \mathrm{x}+46.66$ & 0.98 & $114.35 \%$ \\
R. officinalis & $\mathrm{y}=-3.05 \mathrm{x}+47.18$ & 0.99 & $112.75 \%$ \\
\hline
\end{tabular}


305 The results obtained for the five matrices and the bacterial suspension showed clear 306 distinctions between positive (blue) and negative (grey) droplets (Figure 2). The background 307 (negative droplets) had a similar fluorescence amplitude between samples of the same matrix, 308 and between the five matrices (mean amplitude of fluorescence of negatives droplets ranged 309 from 1,070 to 1,606). The threshold was manually set at an amplitude of fluorescence 310 between 2,000 and 3,000 for each ddPCR run. Compared to the positive control, which is a 311 lysed suspension of pure culture of $X f$, very less rain was observed on the spiked sampled 312 plots, showing high efficiency of the PCR reactions. 

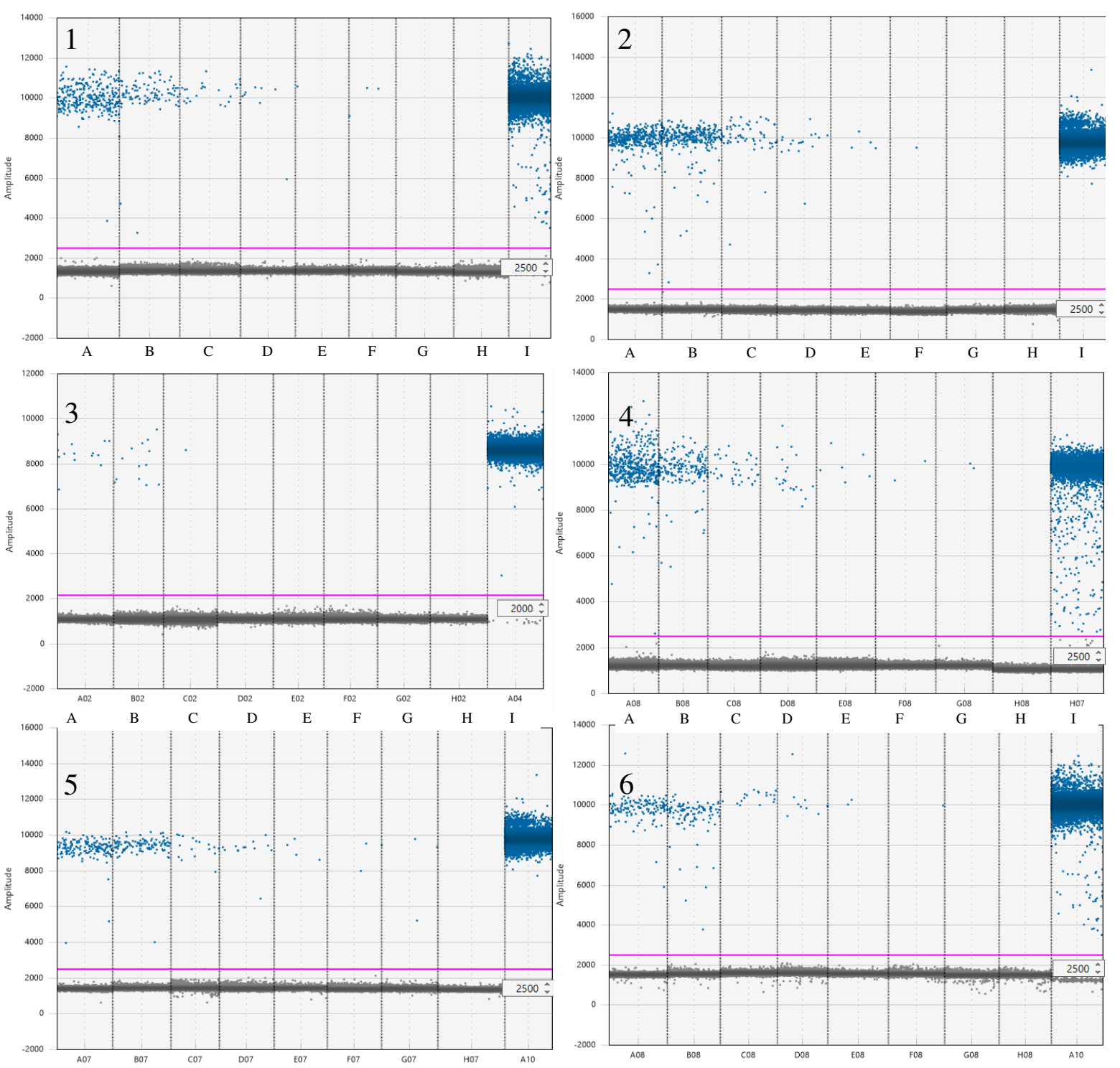

Figure 2: Comparison of the different limits of detection of $X f$ obtained by ddPCR in the bacterial suspension and spiked plant matrices. Pink line: threshold separating negative from positive droplets. Blue dots: positive droplets with amplification. Grey dots: negative

321 droplets with no amplification. 1: Bacterial suspension. 2: Lavandula sp. 3: O. europaea. 4: P. myrtifolia. 5: Q. ilex. 6: R. officinalis. Wells A to G bacterial suspension range of $X f$, A: $1 \times 10^{5}$ b/mL; B: $5 \times 10^{4}$ b/mL; C: $1 \times 10^{4}$ b/mL; D: $5 \times 10^{3}$ b/mL; E: $1 \times 10^{3} \mathrm{~b} / \mathrm{mL} ; \mathrm{F}: 5 \times 10^{2} \mathrm{~b} / \mathrm{mL}$ and G: $1 \times 10^{2} \mathrm{~b} / \mathrm{mL}$. Well H: NTC specific to each matrix. Well I: positive control (lysis suspension of $1 \times 10^{7} \mathrm{~b} / \mathrm{mL}$ of $X f$ ). ddPCR enabled the detection of $X f$ in all the matrices, but at different concentrations (Table 3). The limit of detection was fixed at $5 \times 10^{4} \mathrm{~b} / \mathrm{mL}$, i.e, $2.5 \times 10^{5} \mathrm{~b} / \mathrm{g}$ of plant for $O$. europaea, 
328 at $5 \times 10^{3} \mathrm{~b} / \mathrm{mL}$, i.e, $2.5 \times 10^{4} \mathrm{~b} / \mathrm{g}$ of plant for L. angustifolia and R. officinalis, and at $1 \times 10^{3}$ $329 \mathrm{~b} / \mathrm{mL}$, i.e, $5 \times 10^{3} \mathrm{~b} / \mathrm{g}$ of plant for $Q$. ilex, $P$. myrtifolia and the bacterial suspension. The bias 330 between the detected amount of DNA and the presumed amount of DNA provided was 331 calculated for each matrix at the limit of detection. Compared to the quantity of DNA 332 expected, DNA quantifications of $X f$ were overestimated by $6.54 \%$ and $23.96 \%$ in $Q$. ilex and 333 in the bacterial suspension, respectively. In L. angustifolia, R. officinalis, P. myrtifolia, and $O$. 334 europaea, the DNA quantifications of $X f$ were underestimated by $3.08 \%, 24.36 \%, 32.03 \%$ 335 and $95.60 \%$ respectively. 
Table 3: Mean concentrations estimated in copies/mL $(\mathrm{cp} / \mathrm{mL})$ obtained with ddPCR for the bacterial suspension and the five spiked plant matrices.

\begin{tabular}{|c|c|c|c|c|c|c|c|c|c|c|c|c|}
\hline \multirow{2}{*}{$\begin{array}{l}\begin{array}{l}\text { Dilution range } \\
(\mathrm{b} / \mathrm{mL})\end{array} \\
1 \times 10^{5}\end{array}$} & \multicolumn{2}{|c|}{ Bacterial suspension } & \multicolumn{2}{|c|}{ L. angustifolia } & \multicolumn{2}{|c|}{ O. europaea } & \multicolumn{2}{|c|}{ P. myrtifolia } & \multicolumn{2}{|c|}{ Q. ilex } & \multicolumn{2}{|c|}{ R. officinalis } \\
\hline & $\begin{array}{c}4.02 \times 10^{4} \mathrm{a} \\
\pm 3.63 \times 10^{3}\end{array}$ & $(3 / 3)^{b}$ & $\begin{array}{c}8.07 \times 10^{4} \\
\pm 3.70 \times 10^{3}\end{array}$ & $(3 / 3)$ & $\begin{array}{c}3.38 \times 10^{3} \\
\pm 5.67 \times 10^{2}\end{array}$ & $(9 / 9)$ & $\begin{array}{c}9.08 \times 10^{4} \\
\pm 4.95 \times 10^{3}\end{array}$ & $(3 / 3)$ & $\begin{array}{c}3.58 \times 10^{4} \\
\pm 2.96 \times 10^{3}\end{array}$ & $(3 / 3)$ & $\begin{array}{c}3.62 \times 10^{4} \\
\pm 3.71 \times 10^{3}\end{array}$ & $(3 / 3)$ \\
\hline $5 \times 10^{4}$ & $\begin{array}{c}2.53 \times 10^{4} \\
\pm 2.20 \times 10^{3}\end{array}$ & $(3 / 3)$ & $\begin{array}{c}5.81 \times 10^{4} \\
\pm 2.02 \times 10^{3}\end{array}$ & $(3 / 3)$ & $\begin{array}{c}2.20 \times 10^{3} \\
\pm 5.45 \times 10^{2}\end{array}$ & $(9 / 9)$ & $\begin{array}{c}4.03 \times 10^{4} \\
\pm 4.71 \times 10^{3}\end{array}$ & $(3 / 3)$ & $\begin{array}{c}2.30 \times 10^{4} \\
\pm 9.92 \times 10^{2}\end{array}$ & $(3 / 3)$ & $\begin{array}{c}2.38 \times 10^{4} \\
\pm 3.20 \times 10^{3}\end{array}$ & $(3 / 3)$ \\
\hline $1 \times 10^{4}$ & $\begin{array}{c}5.73 \times 10^{3} \\
\pm 1.14 \times 10^{3}\end{array}$ & $(3 / 3)$ & $\begin{array}{c}1.17 \times 10^{4} \\
\pm 2.19 \times 10^{3}\end{array}$ & $(3 / 3)$ & $\begin{array}{c}5.28 \times 10^{2} \\
\pm 1.90 \times 10^{2}\end{array}$ & $(4 / 9)$ & $\begin{array}{c}6.17 \times 10^{3} \\
\pm 1.39 \times 10^{3}\end{array}$ & $(3 / 3)$ & $\begin{array}{c}4.95 \times 10^{3} \\
\pm 4.04 \times 10^{2}\end{array}$ & $(3 / 3)$ & $\begin{array}{c}5.49 \times 10^{3} \\
\pm 2.98 \times 10^{2}\end{array}$ & $(3 / 3)$ \\
\hline $5 \times 10^{3}$ & $\begin{array}{c}2.84 \times 10^{3} \\
\pm 8.78 \times 10^{2}\end{array}$ & $(9 / 9)$ & $\begin{array}{c}4.85 \times 10^{3} \\
\pm 1.21 \times 10^{3}\end{array}$ & $(3 / 3)$ & $\begin{array}{c}4.25 \times 10^{2} \\
\pm 0.00\end{array}$ & $(1 / 9)$ & $\begin{array}{c}5.14 \times 10^{3} \\
\pm 1.48 \times 10^{3}\end{array}$ & $(3 / 3)$ & $\begin{array}{c}2.81 \times 10^{3} \\
\pm 7.90 \times 10^{2}\end{array}$ & $(9 / 9)$ & $\begin{array}{c}3.78 \times 10^{3} \\
\pm 2.16 \times 10^{3}\end{array}$ & $(9 / 9)$ \\
\hline $1 \times 10^{3}$ & $\begin{array}{c}8.54 \times 10^{2} \\
\pm 2.57 \times 10^{2}\end{array}$ & $(9 / 9)$ & $\begin{array}{c}5.66 \times 10^{2} \\
\pm 1.63 \times 10^{2}\end{array}$ & $(6 / 9)$ & No Call & $(0 / 9)$ & $\begin{array}{c}6.80 \times 10^{2} \\
\pm 2.68 \times 10^{2}\end{array}$ & $(9 / 9)$ & $\begin{array}{c}1.07 \times 10^{3} \\
\pm 5.58 \times 10^{2}\end{array}$ & $(9 / 9)$ & $\begin{array}{c}9.04 \times 10^{2} \\
\pm 1.61 \times 10^{2}\end{array}$ & $(7 / 9)$ \\
\hline $5 \times 10^{2}$ & $\begin{array}{c}6.20 \times 10^{2} \\
\pm 1.19 \times 10^{2}\end{array}$ & $(8 / 9)$ & No Call & $(0 / 9)$ & No Call & $(0 / 9)$ & $\begin{array}{c}5.15 \times 10^{2} \\
\pm 1.43 \times 10^{2}\end{array}$ & $(4 / 9)$ & $\begin{array}{c}7.17 \times 10^{2} \\
\pm 2.59 \times 10^{2}\end{array}$ & $(7 / 9)$ & $\begin{array}{c}6.18 \times 10^{2} \\
\pm 4.56 \times 10^{2}\end{array}$ & $(5 / 9)$ \\
\hline $1 \times 10^{2}$ & $\begin{array}{c}5.84 \times 10^{2} \\
\pm 2.06 \times 10^{2}\end{array}$ & $(6 / 9)$ & $\begin{array}{c}3.73 \times 10^{2} \\
\pm 0.00\end{array}$ & $(1 / 9)$ & No Call & $(0 / 9)$ & $\begin{array}{l}1.77 \times 10^{2} \\
\pm 0.00\end{array}$ & $(1 / 9)$ & $\begin{array}{c}6.23 \times 10^{2} \\
\pm 1.50 \times 10^{2}\end{array}$ & $(7 / 9)$ & $\begin{array}{c}2.01 \times 10^{2} \\
\pm 2.92 \times 10^{1}\end{array}$ & $(2 / 9)$ \\
\hline 0 & No Call & $(0 / 9)$ & No Call & $(0 / 9)$ & No Call & $(0 / 9)$ & No Call & $(0 / 9)$ & No Call & $(0 / 9)$ & No Call & $(0 / 9)$ \\
\hline
\end{tabular}

${ }^{\mathrm{a}}$ : Average $\mathrm{Ct} \pm \mathrm{SD}$

339 b: Number of positive replicates/number of replicates analyzed 


\subsection{Real-time PCR vs ddPCR for Xf detection in spiked samples}

341 As for ddPCR, all the real-time PCR matrix standard curves showed high linearity, as the 342 correlation coefficient $\left(\mathrm{R}^{2}\right)$ was greater than 0.97 (Table 2). This indicated the successful 343 outcomes and good performances of all the assays. Nevertheless, with the exception of $L$. 344 angustifolia, the efficacy range was outside the 90-100\% range, indicating the presence of 345 PCR inhibitors in these plants or incomplete extraction of target DNA.

346 Real-time PCR Harper et al. (2010) was used as a reference method in this study. For all the 347 assays, no mean $\mathrm{Ct}$ values exceeding 38 were recorded at a concentration equal to or higher 348 than the limit of detection, meaning that the limit of detection and positive results were 349 consistent. Moreover, for O. europaea the EPPO PM 7/24 protocol mentions a limit of 350 detection for samples artificially contaminated with $X f$ subsp. multiplex of $100 \%$ at $1 \times 10^{5}$ $351 \mathrm{~b} / \mathrm{mL}$. In this study, the limit of detection of $5 \times 10^{4} \mathrm{~b} / \mathrm{mL}$ was close to that presented in the PM $3527 / 24$ (EPPO, 2018b). The limit of detection of $X f$ in $P$. myrtifolia is known to be $1 \times 10^{3}$, which 353 is the same as the value we found (Legendre B., personal communication). The limits of 354 detection of $X f$ subsp. multiplex for the other matrices could not be compared, as there are no 355 available data.

356 Real-time PCR and ddPCR technology provided equivalent limits of detection for $X f$ in the 357 following matrices: O. europaea, P. myrtifolia and R. officinalis (Table 1, Table 3). The 358 ddPCR technology presented a slightly higher limit of detection of $0.5 \log$ for L. angustifolia. 359 However, a decrease in the limit of detection for $X f$ of $0.5 \log$ for $Q$. ilex and the bacterial 360 suspension were observed. In the conditions of DNA extraction used for this study, and 361 according to the volume of DNA added to the real-time PCR assay, the theoretical limit of 362 detection should be $1 \times 10^{2} \mathrm{~b} / \mathrm{mL}$ for the five plant matrices. These results revealed that $L$. 363 angustifolia and P. myrtifolia may contain fewer real-time PCR inhibitors than Q. ilex and $R$. 364 officinalis. Moreover, the limit of detection of the bacterial suspension was $5 \times 10^{3} \mathrm{~b} / \mathrm{mL}$, 365 meaning that the QuickPick extraction kit may not be $100 \%$ efficient to extract the DNA of 366 bacteria in pure culture. 


\subsection{Xf detection in naturally infected samples: real-time PCR vs} ddPCR

370

371

372

373

374

\begin{tabular}{|c|c|c|c|}
\hline Matrices & $\begin{array}{c}\text { Sample } \\
\text { name }\end{array}$ & $\begin{array}{l}\text { real-time } \\
\text { PCR } \\
\text { Ct means }\end{array}$ & $\begin{array}{l}\text { ddPCR concentration } \\
(\mathrm{cp} / \mathrm{mL})\end{array}$ \\
\hline Calicotome sp & $\mathrm{C} 01$ & $36.41(1 / 2)^{\mathrm{a}}$ & NA $(1 / 12618)^{b}$ \\
\hline L. angustifolia & L01 & $26.08(2 / 2)$ & $1.59 \mathrm{E}+06(6614 / 15814)$ \\
\hline L. angustifolia & L02 & $26.69(2 / 2)$ & $8.82 \mathrm{E}+05(3581 / 13826)$ \\
\hline L. angustifolia & L03 & $31.39(2 / 2)$ & $3.65 \mathrm{E}+04(196 / 15$ 876) \\
\hline L. angustifolia & L04 & $31.78(2 / 2)$ & $4.19 \mathrm{E}+04(227 / 16056)$ \\
\hline P. myrtifolia & P01 & $23.30(2 / 2)$ & $1.61 \mathrm{E}+07(17615 / 17690)$ \\
\hline P. myrtifolia & P02 & $25.04(2 / 2)$ & $4.12 \mathrm{E}+06(11714 / 15$ 550) \\
\hline P. myrtifolia & P03 & $26.90(2 / 2)$ & $1.28 \mathrm{E}+06(5896 / 16$ 720) \\
\hline P. myrtifolia & P04 & $27.25(2 / 2)$ & $9.52 \mathrm{E}+05(4395 / 15$ 894) \\
\hline P. myrtifolia & P05 & $28.10(2 / 2)$ & $5.24 \mathrm{E}+05(2895 / 17$ 733) \\
\hline P. myrtifolia & P06 & $28.44(2 / 2)$ & 5.70E+05 (2 985/16 936) \\
\hline P. myrtifolia & P07 & $28.80(2 / 2)$ & $2.39 \mathrm{E}+05(1446 / 18565)$ \\
\hline P. myrtifolia & P08 & $29.48(2 / 2)$ & $2.11 \mathrm{E}+05(1272 / 18376)$ \\
\hline P. myrtifolia & P09 & $31.20(2 / 2)$ & 5.38E+04 (296/16 332) \\
\hline P. myrtifolia & P10 & $32.21(2 / 2)$ & $3.66 \mathrm{E}+04(216 / 17459)$ \\
\hline P. myrtifolia & P11 & $35.64(2 / 2)$ & $2.63 \mathrm{E}+03(16 / 17$ 898) \\
\hline P. myrtifolia & P12 & $37.00(2 / 2)$ & $8,56 \mathrm{E}+02(3 / 10309)$ \\
\hline P. myrtifolia & P13 & $38.65(2 / 2)$ & $3,25 \mathrm{E}+03(12 / 10848)$ \\
\hline Q. ilex & Q01 & $32.29(2 / 2)$ & $2.13 E+04(113 / 15673)$ \\
\hline Q. ilex & Q02 & $34,85(2 / 2)$ & $1,02 \mathrm{E}+04(39 / 11269)$ \\
\hline Q. ilex & Q03 & $35,80(2 / 2)$ & $3,21 \mathrm{E}+03(13 / 11925)$ \\
\hline Q. ilex & Q04 & $39.00(1 / 2)$ & $4,41 \mathrm{E}+02(2 / 13340)$ \\
\hline
\end{tabular}

A total of 22 samples from infected areas were tested using real-time PCR and ddPCR. Of these, 20 had a mean $\mathrm{Ct}$ value below 38 (ranging from 23.30 to 37.00) (Table 4). However, two samples, P13 and Q04, had a Ct value above 38 (38.65 and 39, respectively), and were considered negative.

Table 4: Comparison of real-time PCR (mean Ct values) and ddPCR (cp/mL) for the detection of Xf in naturally infected samples .

${ }^{a}$ Number of replicates positive for $X f$ detection / total number of analyzed replicates

${ }^{\mathrm{b}}$ Number of positive droplets / total number of droplets (i.e. positives and negatives). 
378 Table 5: Concordance between ddPCR and real-time PCR results on the 22 naturally 379 infected samples.

\begin{tabular}{|c|c|c|c|c|}
\hline & & \multicolumn{2}{|c|}{ Samples analyzed with ddPCR } & \\
\hline & & Positive results & Negative results & \\
\hline \multirow{3}{*}{$\begin{array}{l}\text { Samples analyzed } \\
\text { with real-time PCR }\end{array}$} & Positive results & 19 & 1 & 20 \\
\hline & Negative results & 2 & 0 & 2 \\
\hline & & 21 & 1 & 22 \\
\hline
\end{tabular}

380 
381 The 22 naturally infected samples were then analyzed by ddPCR. The presence of $X f$ was 382 detected in 21 of them, including samples P13 and Q04, with at least two droplets, and a total 383 concentration ranging from $4.41 \times 10^{2} \mathrm{cp} / \mathrm{mL}$ to $1.61 \times 10^{7} \mathrm{cp} / \mathrm{mL}$, confirming the ability of 384 ddPCR to detect $X f$ in naturally infected samples. As only one positive droplet was detected 385 for sample C01, this sample was considered negative by ddPCR. With the exception of 386 samples L04, P06 and P13, the decrease in the Ct value was correlated with an increase in the 387 quantity of DNA detected by ddPCR (Table 4). For each matrix the results obtained by 388 ddPCR and real-time PCR were compared and were highly correlated (Figure 3). 


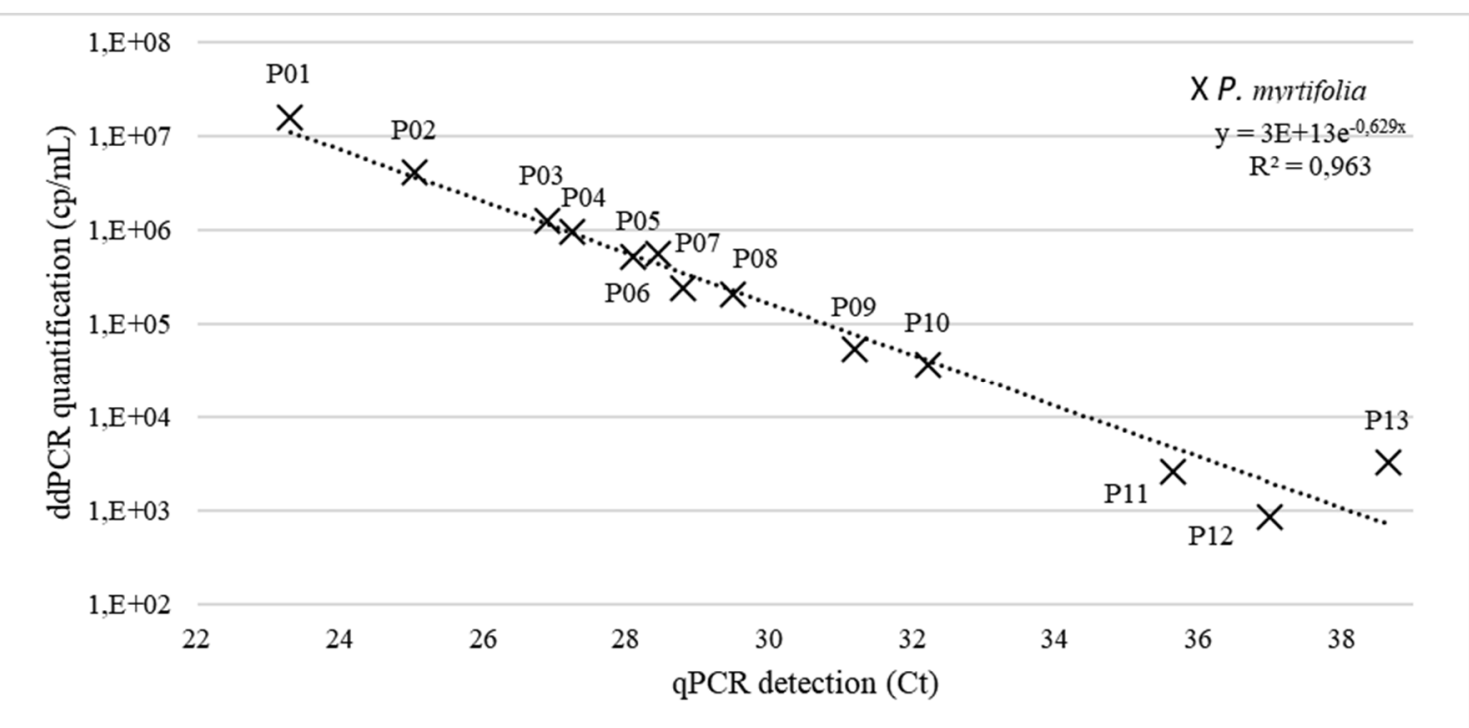

389 A

390

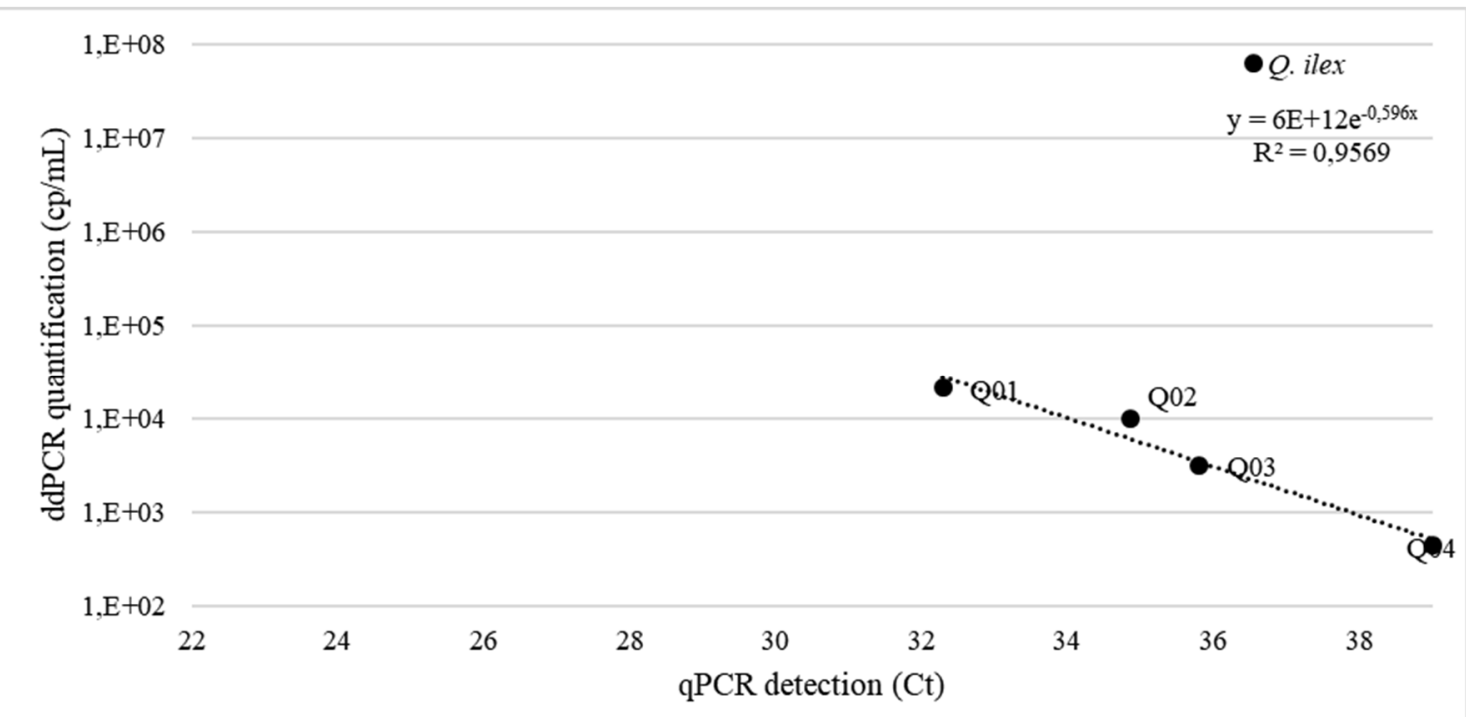

B

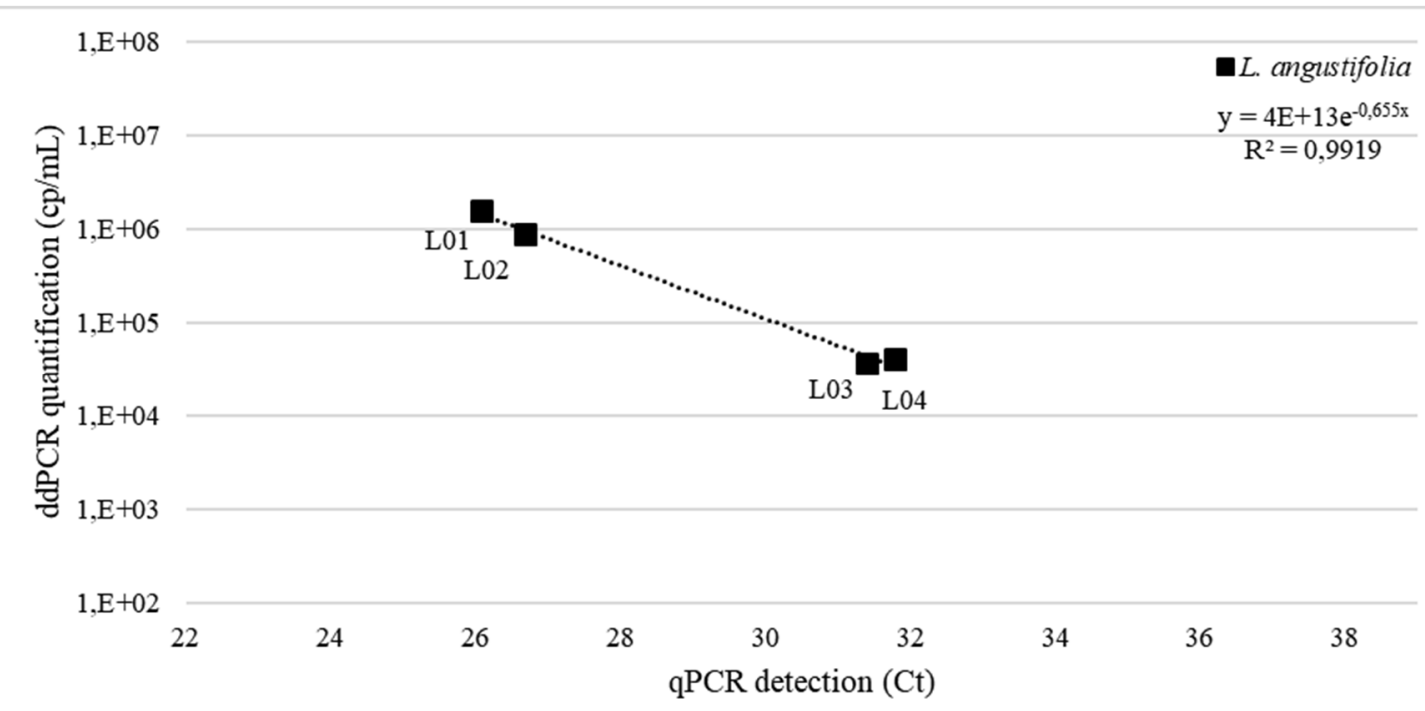

391

C 
392 Figure 3: Correlation between the Ct values obtained by real-time PCR and the amount 393 of target DNA quantified by ddPCR $(\log \mathbf{c p} / \mathbf{m L})$ for the naturally infected samples 394 analyzed. A: samples of P. myrtifolia; B: samples of Q. ilex; C: samples of L. angustifolia. 
396 Since 2013, $X f$ is known to be an emergent plant pathogen in Europe (Saponari et al., 2013). 397 In the countries where $X f$ is present, infected area are growing up every year and threaten 398 productions of economic value (Bucci, 2018; Implementation Decision 2017/2352, 2017; 399 Martinetti and Soubeyrand, 2019; Saponari et al., 2019). As with most plant pathogenic 400 bacteria, no therapeutic solution has been found to kill this pathogen, in addition to vector 401 insect control, early detection and eradication of outbreaks are the only way to prevent the 402 spread of $X f$. Here we present the first transfer in ddPCR of a real-time PCR protocol already 403 used for $X f$ detection in the framework of official survey in the EU and all the setting up steps 404 performed.

405 406 407 408

To implement appropriate control measures, a major issue is getting reliable and sensitive tools capable of early detection of $X f$. The additional challenge of an $X f$ detection tool is its ability to detect the bacterium on its wide range of host plants, some of which are rich in PCR inhibitors. During DNA extraction, the purification step(s) can solve this problem, but inhibitors can still sometimes be co-extracted with bacterial DNA in some plant species. According to Francis et al., 2006; Minsavage et al., 1994; Modesti et al., 2017, dilutions of extracted plant DNA of plants rich in inhibitors could reduce inhibitor effect on PCR efficiency In this study, diluting the DNA extract of L. angustifolia and R. officinalis did not improve the limit of detection using ddPCR, or the obtained results were not sufficiently reproducible. This approach using ddPCR does not seem to be useful and appropriate for $X f$ detection in these two matrices. Nevertheless, more tests should be carried out to support this assumption.

Compared to real-time PCR, ddPCR can be considered as a controversial method. Some studies have revealed that ddPCR was useful to improve pathogen detection sensitivity and to decrease the impact of PCR inhibitors on PCR efficiency (Arvia et al., 2017; Bharuthram et al., 2014; Dong et al., 2018; Rački et al., 2014; Zhao et al., 2016). In other cases, ddPCR was 10 and 100 fold less sensitive than real-time PCR in detecting cytomegalovirus and Leishmaniasis parasite DNA, respectively (Hayden et al., 2013; Ramírez et al., 2019). Dreo et al., reported that ddPCR benefits were dependent of the pathosystem studied (Dreo et al., 2014). The detection of Erwinia amylovora showed similar levels using real-time PCR and ddPCR, while the detection of $R$. solanacearum in low-level infected samples was improved by ddPCR (Dreo et al., 2014). In this study, we easily transfer a real-time PCR in ddPCR with 
only setting up steps. Both methods showed the same limit of detection for O. europaea, $P$. myrtifolia and $R$. officinalis. Real-time PCR allowed better detection of $0.5 \log$ for $L$. angustifolia, and ddPCR allowed better detection of $0.5 \log$ for $Q$. ilex and bacterial suspension.

ddPCR was also compared with real-time PCR on 22 naturally infected samples. Inhibitors seems to act similarly on real-time PCR and ddPCR. As $\mathrm{Ct}$ values were obtained for all samples using real-time PCR, in our study. At the exception of one sample, ddPCR confirmed

434 the real-time PCR results. Moreover, ddPCR was more sensitive because of its low detection 435 threshold fixed at two positive droplets. It allowed the detection of $X f$ in two samples for 436 which their high $\mathrm{Ct}$ values in real-time PCR would have categorized them as negative, due to too late detection, in the framework of official survey. As shown by Dreo et al. (2014) for the detection of $R$. solanacearum, ddPCR technology could offer a real advantage for the detection of plant pathogenic bacteria, and can be applied to the detection of $X f$ in contaminated plants with low concentrations of target DNA (Dreo et al., 2014). ddPCR could contribute to better management of the epidemic and early detection of outbreaks not detected as positive by PCR in real time.

4435 The ddPCR technology requires more steps and is more timeconsuming and expensive than real-time PCR. It does not seem to be suitable for routine analysis. Furthermore, the reaction mix has

446 to handle with care to ensure the generation of the appropriate 447 number of droplets. Nevertheless, ddPCR is a useful technology 448 that should be used in specific cases. ddPCR should be a new tool 449 to confirm the status of samples that have given results at the 450 detection limit or were classified as negative due to late $\mathbf{C t}$ and 451 come from an area where the presence of $\boldsymbol{X} \boldsymbol{f}$ is suspected or plants 452 known to be rich in PCR inhibitors. As for other studies, the transfer 453 of real-time PCR in ddPCR was easily performed (Arvia et al., 2017; 454 Dong et al., 2018; Dreo et al., 2014), other real-time PCR used in the 455 framework of $X f$ survey could be transferred in ddPCR, as the 456 Francis et al., 2006 or Ouyang et al., 2013. Their use could be a 


\section{7 confirmation tool in the case of litigation, complementary to}

458 Harper's results and targeting different parts of the genome.

\section{Conclusion}

460 In this work, we proposed the first suitable ddPCR assay for the detection of $X f$ in plants. We 461 easily transferred a well-known routinely used real-time PCR technique for $X f$ detection in 462 ddPCR. Here, we reported all the set up steps leading to the optimal protocol and its 463 comparison with the current routine method. The results demonstrated the usefulness of 464 ddPCR technology as an alternative method for $X f$ detection in plants, as we were able to 465 detect the bacteria until $1 \times 10^{3} \mathrm{~b} / \mathrm{mL}$ in spiked samples and in naturally infected samples tested 466 negative in real-time PCR. As only two droplets are needed to confirm a sample as positive 467 with ddPCR, this method could confirm the status of samples found to be negative by real468 time PCR due to high $\mathrm{Ct}$ values, and could improve $X f$ detection in low-level infected 469 samples. In addition, as part of Xylella monitoring plan, the ddPCR should classify samples 470 previously detected as undetermined $(\mathrm{Ct}$ value $=35$ to 38$)$ as positive and improve early 471 detection of bacteria. However, due to its cost and the time required to conduct a assay, this 472 technology should be reserved for the confirmation of results. ddPCR should be tested on 473 insects to see whether this technology would still be efficient, and whether it offers a benefit 474 for $X f$ detection in this matrix.

\section{Acknowledgements}

476 We thank Marie-Agnès Jacques, Philippe Reignault, Pascal Gentit and Mathieu Rolland for 477 fruitful discussions and critical reading of the manuscript.

\section{$478 \quad 7 \quad$ Funding}

479 This work was supported by ANSES and the Inra-SPE department. Enora Dupas was co480 funded

by

ANSES

and

the

Inra-SPE

department. 


\section{Bibliography}

482

483

484

485

486

487

488

489

490

491

492

493

494

495

496

497

498

499

500

501

502

503

504

505

506

507

508

509

510

511

512

513

514

515

516

517

518

519

520

521

522

523

524

525

526

527

528

Almeida, R.P.P., Nunney, L., 2015. How Do Plant Diseases Caused by Xylella fastidiosa Emerge? Plant Dis. 99, 1457-1467. https://doi.org/10.1094/PDIS-02-15-0159-FE

Arvia, R., Sollai, M., Pierucci, F., Urso, C., Massi, D., Zakrzewska, K., 2017. Droplet digital PCR (ddPCR) vs quantitative real-time PCR (qPCR) approach for detection and quantification of Merkel cell polyomavirus (MCPyV) DNA in formalin fixed paraffin embedded (FFPE) cutaneous biopsies. J. Virol. Methods 246, 15-20. https://doi.org/10.1016/j.jviromet.2017.04.003

Baldi, P., La Porta, N., 2017. Xylella fastidiosa: Host Range and Advance in Molecular Identification Techniques. Front. Plant Sci. 8. https://doi.org/10.3389/fpls.2017.00944

Bharuthram, A., Paximadis, M., Picton, A.C.P., Tiemessen, C.T., 2014. Comparison of a quantitative Real-Time PCR assay and droplet digital PCR for copy number analysis of the CCL4L genes. Infect. Genet. Evol. 25, 28-35. https://doi.org/10.1016/j.meegid.2014.03.028

Bian, X., Jing, F., Li, G., Fan, X., Jia, C., Zhou, H., Jin, Q., Zhao, J., 2015. A microfluidic droplet digital PCR for simultaneous detection of pathogenic Escherichia coli O157 and Listeria monocytogenes. Biosens. Bioelectron. 74, 770-777. https://doi.org/10.1016/j.bios.2015.07.016

Bucci, E.M., 2018. Xylella fastidiosa, a new plant pathogen that threatens global farming: Ecology, molecular biology, search for remedies. Biochem. Biophys. Res. Commun. 502, 173-182. https://doi.org/10.1016/j.bbrc.2018.05.073

C/2017/4883, 2017. Commission Implementing Directive (EU) 2017/1279 of 14 July 2017 amending Annexes I to V to Council Directive 2000/29/EC on protective measures against the introduction into the Community of organisms harmful to plants or plant products and against their spread within the Community, 184.

Cao, Y., Raith, M.R., Griffith, J.F., 2015. Droplet digital PCR for simultaneous quantification of general and human-associated fecal indicators for water quality assessment. Water Res. 70, 337-349. https://doi.org/10.1016/j.watres.2014.12.008

Cruaud, A., Gonzalez, A.-A., Godefroid, M., Nidelet, S., Streito, J.-C., Thuillier, J.-M., Rossi, J.-P., Santoni, S., Rasplus, J.-Y., 2018. Using insects to detect, monitor and predict the distribution of Xylella fastidiosa: a case study in Corsica. Sci. Rep. 8, 15628. https://doi.org/10.1038/s41598-018-33957-z

Denancé, N., Legendre, B., Briand, M., Olivier, V., de Boisseson, C., Poliakoff, F., Jacques, M.-A., 2017. Several subspecies and sequence types are associated with the emergence of Xylella fastidiosa in natural settings in France. Plant Pathol. 66, 10541064. https://doi.org/10.1111/ppa.12695

Doi, H., Takahara, T., Minamoto, T., Matsuhashi, S., Uchii, K., Yamanaka, H., 2015. Droplet Digital Polymerase Chain Reaction (PCR) Outperforms Real-Time PCR in the Detection of Environmental DNA from an Invasive Fish Species. Environ. Sci. Technol. 49, 5601-5608. https://doi.org/10.1021/acs.est.5b00253

Dong, G., Meng, F., Zhang, Y., Cui, Z., Lidan, H., Chang, S., Zhao, P., 2018. Development and evaluation of a droplet digital PCR assay for the detection of fowl adenovirus serotypes 4 and 10 in attenuated vaccines. J. Virol. Methods. https://doi.org/10.1016/j.jviromet.2018.09.005

Dreo, T., Pirc, M., Ramšak, Ž., Pavšič, J., Milavec, M., Žel, J., Gruden, K., 2014. Optimising droplet digital PCR analysis approaches for detection and quantification of bacteria: a case study of fire blight and potato brown rot. Anal. Bioanal. Chem. 406, 6513-6528. https://doi.org/10.1007/s00216-014-8084-1 
EFSA, 2018. Update of the Xylella spp. host plant database. EFSA J. 16. https://doi.org/10.2903/j.efsa.2018.5408

EPPO, 2018a. EPPO A2 List of pests recommended for regulation as quarantine pests $\begin{array}{lllll}\text { version 2018-09 } & - & \text { [WWW URL }\end{array}$ https://www.eppo.int/ACTIVITIES/plant_quarantine/A2_list (accessed 4.12.18).

EPPO, 2018b. PM 7/24 (3) Xylella fastidiosa. EPPO Bull. 48, 175-218. https://doi.org/10.1111/epp.12469

EPPO, 2014. PM 7/98 (2) Specific requirements for laboratories preparing accreditation for a plant pest diagnostic activity. EPPO Bull. 44. https://doi.org/10.1111/epp.12118

EPPO, 2009. PM 7/97 (1): Indirect immunofluorescence test for plant pathogenic bacteria. EPPO Bull. 39. https://doi.org/10.1111/j.1365-2338.2009.02344.x

Francis, M., Lin, H., Cabrera-La Rosa, J., Doddapaneni, H., Civerolo, E.L., 2006. Genomebased PCR primers for specific and sensitive detection and quantification of Xylella fastidiosa. Eur. J. Plant Pathol. https://doi.org/10.1007/s10658-006-9009-4

Harper, S.J., Ward, L.I., Clover, G.R.G., 2010. Development of LAMP and real-time PCR methods for the rapid detection of Xylella fastidiosa for quarantine and field applications. Phytopathology 100, 1282-1288. https://doi.org/10.1094/PHYTO-06-100168

Hayden, R.T., Gu, Z., Ingersoll, J., Abdul-Ali, D., Shi, L., Pounds, S., Caliendo, A.M., 2013. Comparison of Droplet Digital PCR to Real-Time PCR for Quantitative Detection of $\begin{array}{llll}\text { Cytomegalovirus. } & \text { J. Clin. } & \text { Microbiol. 540-546. }\end{array}$ https://doi.org/10.1128/JCM.02620-12

Hindson, B.J., Ness, K.D., Masquelier, D.A., Belgrader, P., Heredia, N.J., Makarewicz, A.J., Bright, I.J., Lucero, M.Y., Hiddessen, A.L., Legler, T.C., Kitano, T.K., Hodel, M.R., Petersen, J.F., Wyatt, P.W., Steenblock, E.R., Shah, P.H., Bousse, L.J., Troup, C.B., Mellen, J.C., Wittmann, D.K., Erndt, N.G., Cauley, T.H., Koehler, R.T., So, A.P., Dube, S., Rose, K.A., Montesclaros, L., Wang, S., Stumbo, D.P., Hodges, S.P., Romine, S., Milanovich, F.P., White, H.E., Regan, J.F., Karlin-Neumann, G.A., Hindson, C.M., Saxonov, S., Colston, B.W., 2011. High-Throughput Droplet Digital PCR System for Absolute Quantitation of DNA Copy Number. Anal. Chem. 83, 8604-8610. https://doi.org/10.1021/ac202028g

Hoshino, T., Inagaki, F., 2012. Molecular quantification of environmental DNA using microfluidics and digital PCR. Syst. Appl. Microbiol. 35, 390-395. https://doi.org/10.1016/j.syapm.2012.06.006

Huggett, J.F., Foy, C.A., Benes, V., Emslie, K., Garson, J.A., Haynes, R., Hellemans, J., Kubista, M., Mueller, R.D., Nolan, T., Pfaffl, M.W., Shipley, G.L., Vandesompele, J., Wittwer, C.T., Bustin, S.A., 2013. The Digital MIQE Guidelines: Minimum Information for Publication of Quantitative Digital PCR Experiments. Clin. Chem. 59, 892-902. https://doi.org/10.1373/clinchem.2013.206375

Implementation Decision 2017/2352, 2017. DÉCISION D'EXÉCUTION (UE) 2017/ 2352 DE LA COMMISSION - du 14 décembre 2017 - modifiant la décision d'exécution (UE) 2015/ 789 relative à des mesures visant à éviter l'introduction et la propagation dans l'Union de Xylella fastidiosa (Wells et al.) - [notifiée sous le numéro C (2017) 8356]. J. Off. Union Eur. 14.

Košir, A.B., Spilsberg, B., Holst-Jensen, A., Žel, J., Dobnik, D., 2017. Development and inter-laboratory assessment of droplet digital PCR assays for multiplex quantification of 15 genetically modified soybean lines. Sci. Rep. 7, 8601. https://doi.org/10.1038/s41598-017-09377-w 
Landa, B., 2017. Emergence of Xylella fastidiosa in Spain: current situation. Presentation made at the European Conference on Xylella 2017 [WWW Document]. URL https://www.efsa.europa.eu/en/events/event/171113 (accessed 1.17.19).

Li, W., Teixeira, D.C., Hartung, J.S., Huang, Q., Duan, Y., Zhou, L., Chen, J., Lin, H., Lopes, S., Ayres, A.J., Levy, L., 2013. Development and systematic validation of qPCR assays for rapid and reliable differentiation of Xylella fastidiosa strains causing citrus variegated chlorosis. J. Microbiol. Methods 92, 79-89. https://doi.org/10.1016/j.mimet.2012.10.008

Lievens, A., Jacchia, S., Kagkli, D., Savini, C., Querci, M., 2016. Measuring Digital PCR Quality: Performance Parameters and Their Optimization. PLOS ONE 11, e0153317. https://doi.org/10.1371/journal.pone.0153317

Lu, Y., ZHANG, H., WEN, C., WU, P., SONG, S., YU, S., LUO, L., XU, X., 2019. Application of droplet digital PCR in detection of seed-transmitted pathogen Acidovorax citrulli. J. Integr. Agric. 1688. https://doi.org/10.1016/S20953119(19)62673-0

Maheshwari, Y., Selvaraj, V., Hajeri, S., Yokomi, R., 2017. Application of droplet digital PCR for quantitative detection of Spiroplasma citri in comparison with real time PCR. PLOS ONE 12, e0184751. https://doi.org/10.1371/journal.pone.0184751

Martinetti, D., Soubeyrand, S., 2019. Identifying Lookouts for Epidemio-Surveillance: Application to the Emergence of Xylella fastidiosa in France. Phytopathology 109, 265-276. https://doi.org/10.1094/PHYTO-07-18-0237-FI

Minsavage, G., Thompson, C., Hopkins, D., Leite, R., Stall, R., 1994. Development of a Polymerase Chain Reaction Protocol for Detection of Xylella fastidiosa in Plant Tissue. Phytopathology 84, 456. https://doi.org/10.1094/Phyto-84-456

Modesti, V., Pucci, N., Lucchesi, S., Campus, L., Loreti, S., 2017. Experience of the Latium region (Central Italy) as a pest-free area for monitoring of Xylella fastidiosa: distinctive features of molecular diagnostic methods. Eur. J. Plant Pathol. 148, 557566. https://doi.org/10.1007/s10658-016-1111-7

Morisset, D., Štebih, D., Milavec, M., Gruden, K., Žel, J., 2013. Quantitative Analysis of Food and Feed Samples with Droplet Digital PCR. PLOS ONE 8, e62583. https://doi.org/10.1371/journal.pone.0062583

Morley, A.A., 2014. Digital PCR: A brief history. Biomol. Detect. Quantif. 1, 1-2. https://doi.org/10.1016/j.bdq.2014.06.001

Nixon, G., Alexander Garson, J., Grant, P., Nastouli, E., Foy, C., Huggett, J., 2014. Comparative Study of Sensitivity, Linearity, and Resistance to Inhibition of Digital and Nondigital Polymerase Chain Reaction and Loop Mediated Isothermal Amplification Assays for Quantification of Human Cytomegalovirus. Anal. Chem. 86. https://doi.org/10.1021/ac500208w

Nunney, L., Schuenzel, E.L., Scally, M., Bromley, R.E., Stouthamer, R., 2014. Large-Scale Intersubspecific Recombination in the Plant-Pathogenic Bacterium Xylella fastidiosa Is Associated with the Host Shift to Mulberry. Appl. Environ. Microbiol. 80, 30253033. https://doi.org/10.1128/AEM.04112-13

Ouyang, P., Arif, M., Fletcher, J., Melcher, U., Corona, F.M.O., 2013. Enhanced Reliability and Accuracy for Field Deployable Bioforensic Detection and Discrimination of Xylella fastidiosa subsp. pauca, Causal Agent of Citrus Variegated Chlorosis Using Razor Ex Technology and TaqMan Quantitative PCR. PLOS ONE 8, e81647. https://doi.org/10.1371/journal.pone.0081647

Rački, N., Dreo, T., Gutierrez-Aguirre, I., Blejec, A., Ravnikar, M., 2014. Reverse transcriptase droplet digital PCR shows high resilience to PCR inhibitors from plant, soil and water samples. Plant Methods 10. https://doi.org/10.1186/s13007-014-0042-6 
Ramírez, J.D., Herrera, G., Muskus, C., Mendez, C., Duque, M.C., Butcher, R., 2019. Development of a Digital Droplet Polymerase Chain Reaction (ddPCR) assay to detect Leishmania DNA in samples from Cutaneous Leishmaniasis patients. Int. J. Infect. Dis. 79, 1-3. https://doi.org/10.1016/j.ijid.2018.10.029

Saponari, M., Boscia, D., Nigro, F., Martelli, G.P., 2013. Identification of DNA sequences related to Xylella fastidiosa in oleander, almond and olive trees exhibiting leaf scorch symptoms in Apulia (southern Italy). J. Plant Pathol. 95. http://dx.doi.org/10.4454/JPP.V95I3.035

Saponari, M., Giampetruzzi, A., Loconsole, G., Boscia, D., Saldarelli, P., 2019. Xylella fastidiosa in Olive in Apulia: Where We Stand. Phytopathology 109, 175-186. https://doi.org/10.1094/PHYTO-08-18-0319-FI

Schaad, N.W., Postnikova, E., Lacy, G., Fatmi, M., Chang, C.-J., 2004. Xylella fastidiosa subspecies: X. fastidiosa subsp piercei, subsp. nov., X. fastidiosa subsp. multiplex subsp. nov., and X. fastidiosa subsp. pauca subsp. nov. Syst. Appl. Microbiol. 27, 290-300. https://doi.org/10.1078/0723-2020-00263

Schrader, C., Schielke, A., Ellerbroek, L., Johne, R., 2012. PCR inhibitors - occurrence, properties and removal. J. Appl. Microbiol. 113, 1014-1026. https://doi.org/10.1111/j.1365-2672.2012.05384.x

Schuenzel, E.L., Scally, M., Stouthamer, R., Nunney, L., 2005. A Multigene Phylogenetic Study of Clonal Diversity and Divergence in North American Strains of the Plant Pathogen Xylella fastidiosa. Appl. Environ. Microbiol. 71, 3832-3839. https://doi.org/10.1128/AEM.71.7.3832-3839.2005

Voegel, T.M., Nelson, L.M., 2018. Quantification of Agrobacterium vitis from Grapevine Nursery Stock and Vineyard Soil using Droplet Digital PCR. Plant Dis. 102, 21362141. https://doi.org/10.1094/PDIS-02-18-0342-RE

Vogelstein, B., Kinzler, K.W., 1999. Digital PCR. Proc. Natl. Acad. Sci. U. S. A. 96, 92369241.

Wang, M., Yang, J., Gai, Z., Huo, S., Zhu, J., Li, J., Wang, R., Xing, S., Shi, G., Shi, F., Zhang, L., 2018. Comparison between digital PCR and real-time PCR in detection of Salmonella typhimurium in milk. Int. J. Food Microbiol. 266, 251-256. https://doi.org/10.1016/j.ijfoodmicro.2017.12.011

Wei, T., Lu, G., Clover, G., 2008. Novel approaches to mitigate primer interaction and eliminate inhibitors in multiplex PCR, demonstrated using an assay for detection of three strawberry viruses. J. Virol. Methods 151, 132-139. https://doi.org/10.1016/j.jviromet.2008.03.003

Zhao, Y., Xia, Q., Yin, Y., Wang, Z., 2016. Comparison of Droplet Digital PCR and Quantitative PCR Assays for Quantitative Detection of Xanthomonas citri Subsp. citri. PLOS ONE 11, e0159004. https://doi.org/10.1371/journal.pone.0159004 


\begin{tabular}{|c|c|c|c|c|c|c|}
\hline \multirow[b]{2}{*}{$\begin{array}{l}\text { DNA volume } \\
(\mu \mathrm{L})\end{array}$} & \multicolumn{6}{|c|}{ Amount of DNA target detected (cp/well) } \\
\hline & $\begin{array}{l}\text { Bacterial } \\
\text { suspension }\end{array}$ & L. angustifolia & O. europaea & P. myrtifolia & Q. ilex & R. officinalis \\
\hline 2 & 109,0 & 104,0 & 78,7 & 57,1 & 80,9 & 89,9 \\
\hline 4 & 164,5 & 257,0 & 145,0 & 123,0 & 143,5 & 134,5 \\
\hline 6 & 276,0 & 342,0 & 230,0 & 190,0 & 219,5 & 222,5 \\
\hline 8 & 301,5 & 443,5 & 294,0 & 229,7 & 261,5 & 272,0 \\
\hline
\end{tabular}

665 Supplemental data 1: Influence of the DNA extract volume added to the ddPCR reaction 666 mix on the amount of DNA target detected.

667

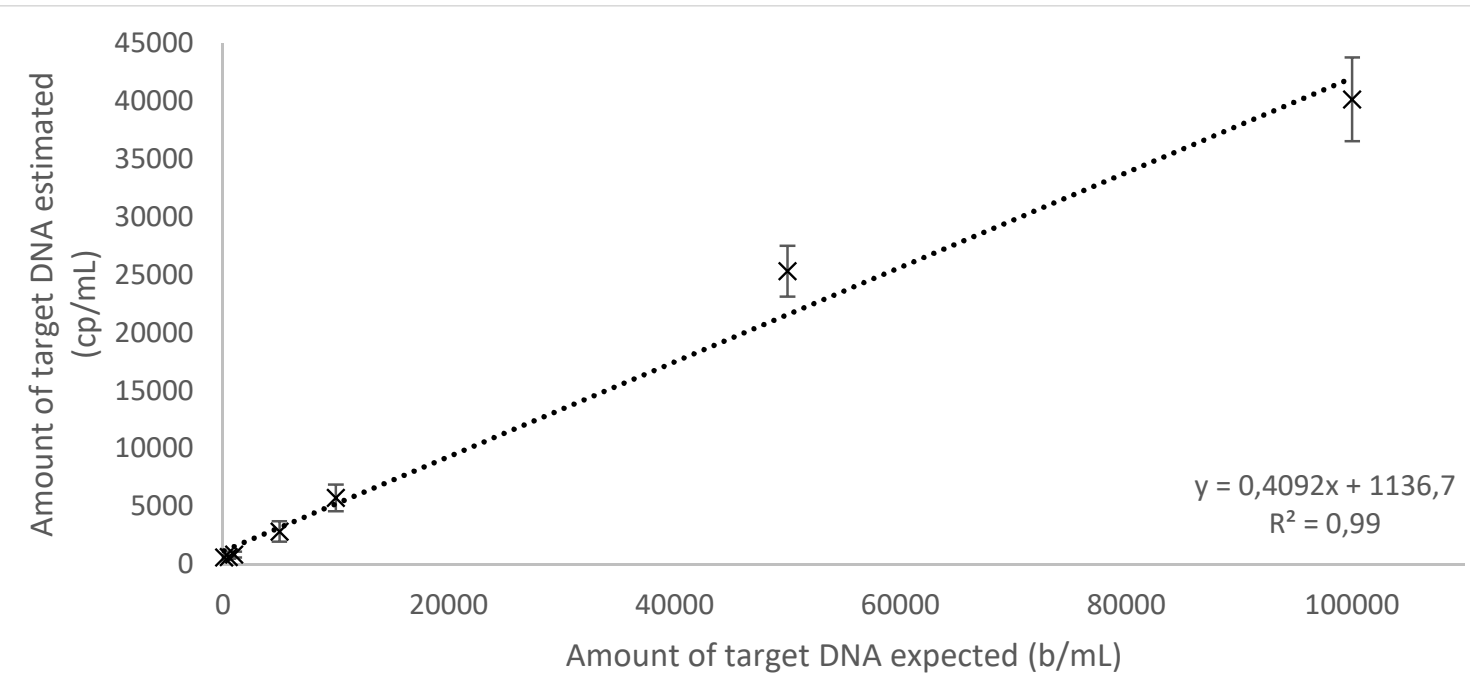

668 Supplemental data 2: Correlation between the amount of target DNA expected and the 669 amount of target DNA quantified by ddPCR for the bacterial suspension.

670 